\title{
Metropolitan-Nonmetropolitan Distinctions in the Determinants of Family Income Inequality
}

William Levernier, Mark D. Partridge and Dan S. Rickman*

Abstract: We examine family income inequality using 1990 Census of Population data for the 3,109 counties and independent cities in the 48 contiguous United States. Numerous characteristics of counties are examined for their role in influencing county income inequality. We particularly focus on differences in labor market effects on income inequality between metropolitan and nonmetropolitan areas. This comparison can help policy makers decide whether nonmetro areas should receive more emphasis in national and state and local economic development policies. We find that nonmetro counties are more affected by labor market factors than metro counties, suggesting additional policies aimed at nonmetropolitan areas to reduce income inequality.

\section{INTRODUCTION}

U.S. income inequality has increased significantly since the 1970s (Katz and Murphy 1992; Freeman and Katz 1994). Especially since 1980, greater income inequality has been reflected in greater returns to skill, experience, and education. Until recently, most studies of the increase in income inequality have used national data focusing on factors such as the decline in manufacturing, declining unionization, and changing demographic patterns (e.g., Bound and Johnson 1992; Blau and Kahn 1996). Increasingly, however, the regional dimensions of income inequality have been explored.

Regional income inequality studies have either used state and majorregion data (Blank and Card 1993; Karoly and Klerman 1994; Topel 1994; Partridge, Rickman, and Levernier 1996; Partridge, Partridge, and Rickman 1998) or metropolitan and county data (e.g., Bartik 1994, 1996; Persky and Tam 1994; Borjas, Freeman, and Katz 1996; Levernier, Partridge, and Rickman 1998). These studies found differences across regions in both the levels of income inequality and their trends over time. Also, the regional studies were useful in examining the causes for rising U.S. income inequality.

Yet, there has been very little examination of how income inequality varies between metropolitan and nonmetropolitan areas. Generally, region-based studies of income inequality and poverty have a strong urban orientation, with a special emphasis on the problems in central cities (e.g., O'Regan and Quigley 1991; Ihlanfeldt 1997). These studies considered the role of various factors, including spatial mismatch and the efficiency of job creation in reducing poverty and

*The authors are, respectively, Associate Professor of Economics, Department of Finance and Economics, Georgia Southern University, Statesboro, GA; Associate Professor of Economics, Department of Economics, St. Cloud State University, St. Cloud, MN; and Professor of Economics and OG\&E Chair in Regional Economic Analysis, Department of Economics and Legal Studies, Oklahoma State University, Stillwater, OK. We thank Ron Moomaw and Jamie Partridge for their helpful comments. 
income inequality. Policies such as enterprise zones have been proposed and implemented to address alleged spatial mismatch problems in central cities. Nonetheless, as discussed below, nonmetropolitan areas have greater family income inequality and higher poverty rates than metropolitan areas (MSAs). ${ }^{1}$ If adverse labor market outcomes have greater effects on nonmetro areas, then policies aimed specifically at addressing nonmetro areas may also be warranted.

Therefore, to further our understanding of the patterns and causes of nonmetropolitan income inequality, this study uses data from the 1990 Census of Population for over 3,000 U.S. counties and independent cities. The use of both metropolitan and nonmetropolitan counties permits us to examine whether the underlying causes of income inequality vary between metro and nonmetro areas. This study extends that of Levernier, Partridge, and Rickman (1998) by separating nonmetro counties from metro counties. Special attention will be given to labor market factors, including employment growth, industry composition, and industry restructuring. We also explore whether demographic characteristics such as education affect income inequality differently between metro and nonmetro areas. In so doing, we attempt to ascertain whether policy makers should give more consideration to the problems of nonmetro areas and, if so, what problems should policies be designed to address.

The next section discusses family income inequality patterns for different county types, drawing comparisons between MSA counties and nonmetro counties. Section III reviews the previous literature and specifies a reduced-form model of income inequality. Section IV presents the empirical results, and the final section contains a summary and some concluding thoughts.

\section{METROPOLITAN/NONMETROPOLITAN COUNTY INCOME INEQUALITY PATTERNS}

County income inequality patterns are examined using 1990 Census of Population data on family income inequality for $1989 .{ }^{2}$ Two well-known measures of family income inequality are calculated. The first is the family income Gini Coefficient scaled up by 100 . The Gini ranges from zero to one with a larger value indicating greater inequality. As is well known, like any measure of inequality, the Gini is imperfect (Levy and Murnane 1992). ${ }^{3}$ For example, the Gini is more sensitive to differences in the middle of the income distribution. The second

\footnotetext{
${ }^{1}$ For example, data from the 1990 Census of Population suggest that average nonmetropolitan county poverty rates are double average suburban county poverty rates and are about 40 percent greater than in central city counties. However, the average nonmetro county poverty rate was below the average central city poverty rate (not the entire central city county), although urbanized nonmetro areas had yet even higher average poverty rates than central cities.

${ }^{2}$ Alternative inequality measures include male wage inequality (e.g., Topel 1994) or household income inequality, but emphasizing families is consistent with the public's concern for the well-being of families. The Census Bureau defines a family as "a group of two or more persons related by birth, marriage, or adoption and residing together in the same household" (Statistical Abstract of the U.S. 1994, p. 6). Overall, over 84 percent of the population lived in families in 1990. By comparison, Karoly and Burtless (1995) constructed different inequality measures (Gini) for households and families, as well as measures adjusted for family size, but their conclusions were unaffected by the particular measure used.

${ }^{3}$ The Gini is derived using the methodology described in Levernier, Rickman, and Partridge (1995).
} 
inequality measure is the variance of the log of family income scaled up by $100 .{ }^{4}$ The variance is more sensitive to differences in the tails of the distribution, which is the exact opposite of the Gini. Yet, despite these differences, the simple correlation between the Gini and the variance of log income in our sample is 0.89 , suggesting that they are closely related.

Counties are chosen as the geographical unit of comparison because they allow for comparison between MSAs and nonmetropolitan areas. Also, because they are the most disaggregated measure available, counties are less likely to suffer from aggregation bias than states or major regions. Generally, counties fairly closely reflect distinct labor markets in nonmetro counties. Likewise, in large MSAs, counties can more closely depict the relevant labor market for particular groups of workers than the entire multicounty MSA. Nonetheless, we are not suggesting that counties represent distinct labor market areas, but rather that such concerns also apply to other arbitrary political units including states, metropolitan areas, and cities. ${ }^{5}$

Table 1 contains the descriptive statistics for both income inequality measures for several different MSA and nonmetropolitan categories of the 3,109 counties and independent cities in the 48 contiguous states. Panel A shows that nonmetropolitan county income inequality is greater than MSA income inequality. In fact, the difference in the average Gini is statistically significant at the $0.1 \%$ level $(t=-6.47)$, but only significant at the $15 \%$ level for the average variance of log income $(t=-1.50)$. It appears then that despite the lack of emphasis given it by policy makers, significant family income inequality also can be found in nonmetropolitan areas. ${ }^{6}$

Panel B shows inequality measures for various subgroupings of the 743 MSA counties. Average family income inequality is initially negatively related to MSA size up through a population of between two and five million. However, income inequality is greater for counties in MSAs with a population over five million. The income inequality differences between counties in MSAs of less than 350,000 people and counties in MSAs with between two and five million people are statistically significant ( $t=4.68$ for the Gini and $t=3.77$ for the variance of the $\log$ of income). Similarly, the differences are statistically significant between counties in MSAs with a population of over five million and counties in MSAs with populations between two and five million ( $t=-2.06$ for the Gini and $t=-2.18$ for the variance of the log of income).

${ }^{4}$ The 1990 Census of Population reports total family income for 25 different income classes. Following the previous literature, we calculated the variance of log income by assuming that each family in the income class is at the midpoint of its income class for the first 24 income classes. For the open-ended category, we assumed that every family is at the mean income of the income category. Overall, this technique tends to slightly understate the actual dispersion in income, although there are no reasons to assume that this measurement concern is systematic across the sample.

${ }^{5}$ One advantage that counties have over MSAs (or most other alternatives) as the unit of measurement is that public policy making is easier to undertake at the county level. By contrast, uniform government policies are difficult to implement in MSAs because MSAs are usually made up of disjointed sets of communities and governments (which could even be in different states).

${ }^{6}$ Regarding the Gini (x 100), Table 1 reveals that the metro-nonmetro average difference was about 1.05 . By comparison, U.S. Bureau of Census data indicate that the rather dramatic increase in the family income Gini totaled about 3.01 during the 1980s. This suggests that the metro-nonmetro differential is nontrivial. 
TABLE 1

Inequality by County Type

\begin{tabular}{|c|c|c|c|}
\hline Region & $\begin{array}{l}\text { Gini } x 100 \\
\text { (std. dev.) }\end{array}$ & $\begin{array}{l}\text { Variance of } \\
\text { Log Income } x 100 \\
\text { (std. dev.) }\end{array}$ & $\begin{array}{c}\text { Sample } \\
\text { Size }\end{array}$ \\
\hline \multicolumn{4}{|l|}{ Panel A } \\
\hline MSA Counties & $\begin{array}{c}37.85 \\
(3.78)\end{array}$ & $\begin{array}{c}66.61 \\
(14.37)\end{array}$ & 743 \\
\hline Nonmetro Counties & $\begin{array}{l}38.90 \\
(4.09)\end{array}$ & $\begin{array}{c}67.51 \\
(14.07)\end{array}$ & 2,366 \\
\hline \multicolumn{4}{|l|}{ Panel B } \\
\hline Counties in MSAs of less than 350,000 & $\begin{array}{l}38.59 \\
(3.36)\end{array}$ & $\begin{array}{c}68.77 \\
(12.72)\end{array}$ & 280 \\
\hline Counties in MSAs between 350,000 and 1 million & $\begin{array}{c}37.78 \\
(3.45)\end{array}$ & $\begin{array}{c}66.31 \\
(12.68)\end{array}$ & 227 \\
\hline Counties in MSAs between 1 million and 2 million & $\begin{array}{l}37.19 \\
(3.75)\end{array}$ & $\begin{array}{c}63.94 \\
(14.61)\end{array}$ & 115 \\
\hline Counties in MSAs between 2 million and 5 million & $\begin{array}{l}36.46 \\
(4.27)\end{array}$ & $\begin{array}{c}62.49 \\
(15.46)\end{array}$ & 109 \\
\hline Counties in MSAs over 5 million & $\begin{array}{l}41.17 \\
(7.80)\end{array}$ & $\begin{array}{c}84.86 \\
(35.17)\end{array}$ & 12 \\
\hline Suburban Counties in Large MSAs ${ }^{a}$ & $\begin{array}{l}36.16 \\
(3.16)\end{array}$ & $\begin{array}{c}60.53 \\
(10.98)\end{array}$ & 335 \\
\hline Suburban Counties in Small MSAs ${ }^{b}$ & $\begin{array}{l}37.23 \\
(3.62)\end{array}$ & $\begin{array}{c}64.91 \\
(13.29)\end{array}$ & 91 \\
\hline 91 Single-County MSA & $\begin{array}{l}39.19 \\
(3.13)\end{array}$ & $\begin{array}{c}69.51 \\
(11.09)\end{array}$ & 161 \\
\hline 161 Central City Countyc & $\begin{array}{l}40.14 \\
(3.75)\end{array}$ & $\begin{array}{c}77.67 \\
(16.92)\end{array}$ & 156 \\
\hline \multicolumn{4}{|l|}{ Panel C } \\
\hline Nonmetro Counties of greater than 25,000 & $\begin{array}{l}38.72 \\
(3.71)\end{array}$ & $\begin{array}{c}68.02 \\
(13.83)\end{array}$ & \\
\hline Nonmetro Counties between 10,000 and 25,000 & $\begin{array}{c}39.16 \\
(4.00)\end{array}$ & $\begin{array}{c}68.58 \\
(13.86)\end{array}$ & 871 \\
\hline Nonmetro Counties of less than 10,000 & $\begin{array}{l}38.77 \\
(4.55)\end{array}$ & $\begin{array}{c}65.72 \\
(14.40)\end{array}$ & 732 \\
\hline
\end{tabular}

a Suburban MSA counties are defined as all counties in a multiple-county MSA that do not contain the largest city in the metropolitan area. A large MSA is defined as a total MSA population of greater than 350,000 .

bSuburban MSA counties are defined as all counties in a multiple-county MSA that do not contain the largest city in the metropolitan area. A small MSA is defined as a total MSA population of less than 350,000 .

cA central city MSA county is defined as the county containing the largest city in a multicounty MSA.

Panel B also shows income inequality values for four different categories of MSA counties: (1) suburban counties in MSAs with more than 350,000 people; (2) suburban counties in MSAs with less than 350,000 people; (3) single-county MSAs; and (4) counties that contain the central city (or largest city) of a multicounty MSA. ${ }^{7}$ As expected, the reported values show that counties that contain the central city have greater income inequality than both categories of suburban coun-

'For smaller MSAs, counties that do not include the central city can be otherwise quite rural. Thus, we separated suburban counties into larger and smaller MSAs using an MSA population of 350,000 as the dividing point. We tried alternative division points above and below 350,000 without effect. Some outlying counties in larger MSAs may also be somewhat rural in nature, but such counties represent a much smaller proportion. 
ties, with the differences statistically significant. ${ }^{8}$ The two suburban categories have more similar levels of income inequality; however, small-MSA suburban counties have a significantly larger average Gini and variance $(t=-2.57$, $t=-2.89$, respectively). Likewise, central city and single-county MSAs have more similar Gini and variance measures, although the differences are also significant $(t=-2.44, t=-5.06$, respectively). Panel $C$ shows values for the two income inequality measures for three different nonmetropolitan population categories. At this stage, for nonmetro areas, there is no clear economically meaningful relationship between population and income inequality.

\section{MODEL OF REGIONAL FAMILY INCOME INEQUALITY}

Since differences in income inequality between metropolitan and nonmetropolitan counties, and between categories within these divisions, could be related to variations in their characteristics and the importance of these characteristics, we develop a model to examine the sources of these differences. Our model closely follows previous region-based models that have been used to explain income inequality (e.g., Levernier, Partridge, and Rickman 1998; Partridge, Rickman, and Levernier 1996; Partridge, Partridge, and Rickman 1998). Generally, most of the explanatory factors can be found in the recent income inequality literature.

In equation (1), family income inequality for MSA and nonmetropolitan counties is written in general form for county $i$, in state $s$ :

Inequality ${ }_{\text {is }}^{k}=\mathrm{f}\left(\right.$ Metro/Nonmetro ${ }^{k}{ }_{\mathrm{is}}$, Econ Develop $^{\mathrm{k}}{ }_{\mathrm{is}}$ Industry Comp ${ }_{\mathrm{is}}^{\mathrm{k}}$ Human K/Demog ${ }^{k}$ is $)+\sigma_{s}^{k}$,

where $\mathrm{k}$ represents either MSA or nonmetro status. ${ }^{9}$ Two alternative measures of Inequality, both scaled up by 100, are used: (1) the Gini coefficient; and (2) the variance of the log of family income. Metro/Nonmetro is a vector of variables to account for the category of the county and county population effects. Econ Develop is a vector of income, employment growth, and labor market traits of the county. Industry Comp is a vector that controls for the industry composition of the county. The Human K/Demog vector controls for the labor market skills and demographic characteristics of the county's population. The state fixed effects, $\sigma^{k}{ }_{s}$, reflect factors such as different state-level government policies and unique cultural or institutional characteristics. If such unmeasured attributes are correlated with the other variables, omitting the state fixed effects biases the coefficient estimates.

Several Metro/Nonmetro county-type variables are included to capture possible income inequality differences across county types that remain after accounting for variations in their characteristics. First, metropolitan and nonmetropolitan population may influence income inequality. For metro counties,

${ }^{8}$ The $t$-statistics for the differences between large-MSA suburban county and central city county average Gini and average variance were $-\mathbf{1 1 . 4 9}$ and -11.57 , respectively. The $t$-statistics for the differences between small-MSA suburban county and central city county average Gini and average variance were -6.01 and -6.57 , respectively.

${ }^{9}$ Unless otherwise indicated, all variables are derived from the 1990 Census of Population. 
population for the entire MSA is used, while county population is used in nonmetropolitan counties. For both metro and nonmetro areas, variations in population reflect differences in economies (or diseconomies) of scale, agglomeration effects, and cost-of-living differentials. On one hand, Garofalo and Fogarty (1979) suggested that urban agglomeration effects relatively benefit high-skilled employees. On the other hand, greater population may favor less-skilled workers. This can occur if less-skilled workers have inferior labor market information or are less geographically mobile, but increased opportunities to achieve a suitable labor market match mitigate such effects. Thus, the relationship between MSA and nonmetro population with family income inequality is ambiguous.

The second Metro/Nonmetro category of variables reflects the various categories of counties within an MSA used in Table 1 and only appears in the MSA specification. As Table 1 shows, central city counties (and single-county MSAs) have greater average income inequality than suburban counties. This can occur if underclass families are concentrated in the central city, which can also contain very wealthy pockets since the affluent may place a high value on commuting time (LeRoy and Sonstelie 1983). Problems for the urban poor are exacerbated if they have difficulty in obtaining transportation from the central city to the more economically vibrant suburbs (Zax and Kain 1996) or lack information regarding the MSA's spatial distribution of jobs (Ihlanfeldt 1997). (Other "spatial mismatch" factors are summarized in Holzer 1991.) Conversely, in addition to benefitting from closer proximity to employment growth, suburban counties could be more homogenous in terms of family income. For example, Tiebout sorting through exclusionary zoning policies can produce relative economic homogeneity in the suburbs (O'Regan and Quigley 1991). The omitted category is single-county MSAs, so that a positive metro category dummy coefficient would imply that the metro category has greater income inequality, ceteris paribus, than single-county MSAs. A priori, the relationship between single-county MSAs and income inequality is unclear, depending upon whether central city or suburban features dominate.

The Econ Develop vector includes several labor market variables that may relate to local economic development policy. The first labor market variable measures industrial restructuring. Recent structural changes in the economy appear to have increased job anxiety in the work force. Not only can structural change and corporate restructuring affect total employment growth, it also can increase longterm or chronic unemployment if there are mobility costs of changing sectors (Partridge and Rickman 1998). Displaced workers often encounter extended spells of unemployment and suffer large declines in average post-displacement earnings (about 10 percent), depending upon the sector from which the worker was laid off (Jacobson, LaLonde, and Sullivan 1993; Carrington and Zaman 1994) and local labor market conditions (Howland and Peterson 1988). Yet, as far as we know, the structural change-income inequality relationship has only been explored by Levernier, Partridge, and Rickman (1998). They, however, ignored the issue of whether the effects differed by metro and nonmetro areas. 
The structural change measure that we use is Allen and Freeman's (1995) index of structural change (ISC). The ISC is the sum of absolute changes in the share of one-digit SIC industry employment between the initial period and ending period, divided by two. The ISC reflects the percentage shift in the labor force that is necessary to equate industry structure across the two periods.

The relevant period for structural change to have an impact on income inequality depends upon the time required for workers to become reemployed, migrate to other regions, or drop out of the labor force. There are no strong reasons to expect that these conditions are identical across MSA and nonmetropolitan counties. For example, in larger MSA labor markets, it may be easier for workers to find a suitable labor market match after displacement. However, if on average there are greater firm- or industry-specific skills in MSA jobs, it may be harder for displaced MSA workers to attain their previous earnings. Thus, to determine the time frame statistically for MSA and nonmetro counties, we separately consider three alternative ISC time lengths: $1980-1990,1985-1990$, and 1988-1990. ${ }^{10}$

Economic growth is another economic development factor that can influence income inequality. Some studies have found that economic growth (not level of development) disproportionately benefits less-skilled workers (Topel 1994; Bartik 1994, 1996), which reduces income inequality. Low-skilled workers especially gain when low-skilled workers' wages (and hours) respond more to cyclical shifts or, alternatively, when low-skilled workers obtain needed work experience during economic expansion. In particular, we expect the equalizing effects of economic growth to be stronger in nonmetro areas because rural low-income families should not face the transportation and information constraints (within the county) that supposedly face low-income families and minorities in central cities (via traditional urban spatial mismatch). With lower geographic mobility of nonmetro households across counties, nonmetro households may be more dependent on employment growth within the county.

Yet, other studies are less sanguine about the ability of economic growth to reduce income inequality. For example, Blank and Card (1993) found that the prolonged economic expansion of the 1980s had very little impact on poverty rates. Similarly, Cutler and Katz (1991) and Karoly (1993) found that economic growth had minimal effects on national income inequality, while Partridge, Rickman, and Levernier (1996) found similar results at the state level. Thus, the expected effect of economic growth on income inequality is ambiguous.

The two economic growth variables included in Econ Develop are 1980 to 1990 employment growth and 1988 to 1990 employment growth, which are derived from U.S. Department of Labor data (USA Counties CD-ROM). Both employment measures are included to capture the independent effects of shortterm and long-term economic growth, as well as to account for the possibility that

${ }^{10}$ The ISCs are constructed using the U.S. Department of Commerce's Regional Economic Information System data series. A problem with this data is that some counties have industries whose employment is not disclosed. How the disclosure problem was handled in the construction of the ISC variables is described in the Data Appendix. 
short-term and long-term economic growth are negatively correlated (Bartik 1993). Bartik $(1994,1996)$ argues that migration should diminish the progressive effects of economic growth in the long term, suggesting that the short-term employment measure is more likely to be negatively related to income dispersion. ${ }^{11}$

Greater male and female labor force participation also affects wage and income inequality. ${ }^{12}$ Increased labor force participation reduces family income inequality when it is predominately concentrated in the lower rungs of the economic distribution, which is likely for male labor force participation. However, the expected effect of female labor force participation is not as clear. If married women from low-income families enter the labor force in response to inadequate earnings of their husbands (Bradbury 1990; Partridge, Partridge, and Rickman 1998), female labor force participation reduces income inequality. Conversely, in the 1980s, married females' earnings were increasingly correlated with their husband's incomes (e.g., Karoly and Burtless 1995; Juhn and Murphy 1997), which implies that greater female participation increases family income inequality. Likewise, it is unclear whether labor force participation has different impacts between MSAs and nonmetro areas.

The natural log of average earnings per family is included as a measure of the level of economic development. The Kuznets (1955) hypothesis suggests that greater average levels of income are negatively related to income inequality, which has been found in some previous studies (e.g., Persky and Tam 1994). Yet, many studies have found evidence that income inequality begins to rise at higher levels of income (Garofalo and Fogarty 1979; Partridge, Rickman, and Levernier 1996). In fact, this can occur if advanced economic development is associated with a bimodal distribution of jobs with increasing returns to skills. For example, most advanced economies have experienced greater income inequality since 1980 (Davis 1992).

To control for business ownership patterns, the percent of personal income that is due to self-employment is included in the model. The self-employment income share coefficient is expected to be positive because the very nature of small business reflects variable levels of profitability. Small business also can be associated with lower wages, which increases income inequality.

Another reason why income inequality can differ across counties is differences in industry composition. For example, large interindustry wage differentials have been found across workers, even after controlling for a multitude of individual human capital effects (Katz and Summers 1989). It has been frequently argued that the decline of high-paying manufacturing and other goods-producing

\footnotetext{
${ }^{11}$ An alternative way of viewing employment growth's effect is as a lagged and contemporaneous influence. Specifically, the employment growth terms can be written as:

$\beta 1(1980-90$ EMP GROWTH) + $\beta 2(1988-1990$ EMP GROWTH).

This can rearranged as:

11(1980-87 EMP GROWTH + 1988-1990 EMP GROWTH) + $\beta 2(1988-1990$ EMP GROWTH).

This can be further rewritten as:

$\beta 1(1980-87$ EMP GROWTH $)+(\beta 1+\beta 2)(1988-1990$ EMP GROWTH $)$.

Nonetheless, interpreting the coefficients in this alternative fashion did not change any of our conclusions.

${ }^{12}$ For a survey of labor force participation's influence on income inequality, see Cancian, Danziger, and Gottschalk (1993).
} 
jobs is an important cause of greater income inequality (Bluestone 1990). Borjas and Ramey (1995) suggested that the employment share of durable good manufacturing was of particular importance because of the rents received by its workers. They showed that metropolitan areas with a greater share of tradeimpacted durable good industries had lower educational differentials. However, other studies have found that industry structure played little role in influencing income inequality (Bound and Johnson 1992; Bartik 1996).

The industry composition vector in equation (1) contains 15 industry employment shares. The share in public administration is omitted to avoid perfect collinearity. As such, the industry share coefficients are measured relative to public administration. The 15 industries generally reflect one-digit categories except that the large one-digit SIC service sector is split into several subsectors to capture that sector's heterogeneity. Since the administrative pay structure of government reduces wage dispersion, most sectors should have greater income inequality than the public administration sector. Greater employment shares in "high-paying" sectors such as manufacturing, transportation, communications, and mining may reduce income inequality more than average because these sectors have traditionally provided many blue-collar workers with access to "good" jobs. Nonetheless, one recent trend is that manufacturing plants have located in rural "greenfield" locales to take advantage of low wages and a smaller probability of unionization. If so, manufacturing may not reduce nonmetro family income inequality to the degree that it does in MSAs. Service industries, on the other hand, have been traditionally associated with relatively more income inequality. By including a broad range of service industries, it can be determined if the service sector universally raises income inequality.

The Human K/Demographic vector includes several variables to account for county labor force composition. Related to labor force skills, two education attainment variables are included: (1) the percent of the population above 24 years old who are four-year college graduates; and (2) the percent of the population above 24 years old who are at least high school graduates but who do not have a four-year college degree. The percent of the population that are high school dropouts is the omitted group, suggesting that the two education coefficients should be measured relative to high school dropouts.

Given that high school and some college represents the middle of the educational distribution, it is expected that a greater share of this group relative to high school dropouts reduces income inequality. A greater share of college graduates relative to high school dropouts implies a greater supply of college educated workers, which in turn should reduce the educational wage differential (and income inequality). Yet, it is well known that both the college/high school dropout differential and the college/high school wage differential have risen since 1980, perhaps due to skill-biased technological change (Bound and Johnson 1992; Katz and Murphy 1992). Therefore, in a mechanical sense, irrespective of its net impact, a greater share of college graduates likely has a more positive impact on 
income inequality in the 1990s than in did in the 1970s. Nonetheless, if technological change is playing a greater role in urban areas, greater educational attainment levels may have a less equalizing impact on incomes in MSAs than in nonmetro counties.

A greater dispersion in human capital or educational attainment also should increase income inequality (Hirsch 1978). Thus, to separate educational attainment effects from education dispersion effects, the standard deviation of years of education is also included in the model. ${ }^{13}$

Blank (1989) and Blank and Card (1993) show that changes in family structure are an important cause of greater income inequality since 1970. Thus, the model includes the percent of female-headed families. A greater share of femaleheaded families represents an important factor since these families simply have one less available worker. Also, female heads are especially hindered in the labor market when the availability of child care is limited. ${ }^{14}$ To control for age structure effects, the shares of the population between 18 and 24,60 and 64, and 65 and over are included. To account for the influence of family size on income inequality, average number of own children per family is included. Finally, to account for the racial composition of the population, the percent of the population that is AfricanAmerican and the percent of the population that is minority but not AfricanAmerican, are included in the specification. The impact of the two minority shares is ambiguous. Lower minority earnings (perhaps due to discrimination) increases income inequality. Yet, at some point, greater minority shares of the population may reflect a more homogenous population socioeconomically, which implies less family income inequality.

The share of the population who lived in the county in 1985 (five years before the census) and the percent of the population who internationally immigrated after 1985 are the final demographic variables. ${ }^{15}$ The original resident share is a measure of the stability of the county's population. A larger share of the population that had previously lived in the county is negatively related to both the county's native in-migration rate and to the native out-migration rate (ceteris paribus), with some in-migration being a necessary condition for the original share to deviate from 100 percent.

Less gross out-migration in response to layoffs or reduced wage rates would increase income inequality. Similarly, since they are more educated on average, an influx of domestic migrants may reduce the earnings of higher skilled original residents, compressing the income distribution. Greater in-migration also may increase competition for local businesses, which can diminish existing economic rents. Therefore, a larger share of the population that had lived in the

\footnotetext{
${ }^{13}$ In sensitivity analysis, omitting the standard deviation of years of education had almost no influence on the two education attainment coefficients or on the other results.

${ }^{14}$ For example, Partridge and Rickman (1996) found that unemployment was higher for females with very young children in Georgia, suggesting a problem with the availability of affordable, convenient child care.

${ }^{15}$ Since recent international immigrants are much less likely to have been assimilated into the labor market, foreign immigrants in the last five years before the census are emphasized. However, experiments were conducted by also including the share of foreign immigrants from 1960-69, 1970-79, and 1980-1984, but these variables were insignificant.
} 
county in 1985 is expected to increase income inequality. To be sure, if nonmetro product and labor markets are more insular than metro markets, these migration factors may reduce income inequality more in nonmetro areas.

Since foreign immigrants typically have among the lowest skills in the population (Borjas, Freeman, and Katz 1992), they directly increase income inequality. In addition, a greater influx of low-skilled immigrants may reduce the low-skilled wage rate (Topel 1994). However, in a regional context the influence of international immigrants is complicated. Foreign immigrants have a mixed impact on wages because less-skilled natives tend to migrate away from locales that have received an influx of foreign immigrants (Frey 1995). Thus, greater shares of foreign immigrants may appear to have little impact in gateway communities (e.g., at the county level), even when there is an impact nationally. For example, Borjas, Freeman, and Katz (1996) found that the share of foreign immigrants in a metro area was insignificant in affecting wages, but the coefficient was negative and significant when they examined states or regions.

\section{EMPIRICAL RESULTS}

Table 2 shows the unweighted variable means and standard deviations. Columns (1) and (2), respectively, report the descriptive statistics for the 743 MSA counties and the 2,366 nonmetro counties. Columns (3) and (4) report descriptive statistics for both central city and suburban counties.

The large sample sizes in columns (1) and (2) virtually ensure that there will be statistically significant differences between the MSA and nonmetropolitan county averages. Yet, there are also some meaningful differences. For example, MSA counties have greater levels of average income, employment growth during the 1980s, and male and female labor force participation. From 1980 to 1990, employment growth averaged 40 percent in MSA counties, but only 16 percent in nonmetro counties. However, the employment growth rates of metro and nonmetro counties appeared to converge between 1988 and 1990. In addition, metro counties experienced smaller sectoral reallocations, especially in the latter 1980s. For example, it would require 5.7 percent of the typical MSA's labor force to change one-digit SIC sectors between 1985 and 1990 to equate industry composition across the two periods, compared to 6.7 percent for nonmetro counties. Nonmetro counties have relatively more agriculture and mining, while MSA counties have greater shares of employment in trade; finance, insurance, and real estate (FIRE); professional services; and business services. Also, metro counties have higher shares of college graduates, female-headed families, and recent foreign immigrants.

As above, with the large sample sizes in columns (3) and (4), most of the average characteristics within metropolitan areas are different in a statistical sense. Of economic consequence, suburban counties have experienced both more recent employment growth and more structural changes compared to central city counties. Suburban counties have appreciably higher employment shares in man- 
ufacturing and construction, but lower shares in trade, health services, and educational services. Male and female labor force participation rates are higher in suburban areas. Central city counties have higher shares of college graduates, minority populations, and recent foreign immigrants.

TABLE 2

Descriptive Statistics

\begin{tabular}{|c|c|c|c|c|}
\hline Variable & $\begin{array}{c}\text { Nonmetro } \\
\text { Counties } \\
\text { (std. dev.) } \\
(1)\end{array}$ & $\begin{array}{c}\text { Metro } \\
\text { Counties } \\
\text { (std. dev.) } \\
\text { (2) }\end{array}$ & $\begin{array}{l}\text { Central City } \\
\text { Counties } \\
\text { (std. dev.) } \\
\text { (3) }\end{array}$ & $\begin{array}{c}\text { Suburban } \\
\text { Counties } \\
\text { (std. dev.) } \\
\text { (4) }\end{array}$ \\
\hline \multicolumn{5}{|l|}{ Dependent Variables: } \\
\hline Gini $x 100$ & $\begin{array}{l}38.90 \\
(4.09)\end{array}$ & $\begin{array}{l}37.85 \\
(3.78)\end{array}$ & $\begin{array}{l}39.82 \\
(3.50)\end{array}$ & $\begin{array}{l}36.39 \\
(3.29)\end{array}$ \\
\hline Variance Log of Income x 100 & $\begin{array}{c}67.51 \\
(14.07)\end{array}$ & $\begin{array}{c}66.61 \\
(14.37)\end{array}$ & $\begin{array}{c}73.52 \\
(14.81)\end{array}$ & $\begin{array}{c}61.47 \\
(11.63)\end{array}$ \\
\hline \multicolumn{5}{|l|}{ Metro/Nonmetro: } \\
\hline Single-County MSA & na & $\begin{array}{c}0.22 \\
(0.41)\end{array}$ & $\begin{array}{c}0.51 \\
(0.50)\end{array}$ & na \\
\hline Small-MSA Suburban Countya & na & $\begin{array}{c}0.12 \\
(0.33)\end{array}$ & na & $\begin{array}{c}0.21 \\
(0.41)\end{array}$ \\
\hline Large-MSA Suburban County ${ }^{b}$ & na & $\begin{array}{c}0.45 \\
(0.50)\end{array}$ & na & $\begin{array}{c}0.79 \\
(0.41)\end{array}$ \\
\hline Central City Countyc & na & $\begin{array}{c}0.21 \\
(0.41)\end{array}$ & $\begin{array}{c}0.49 \\
(0.50)\end{array}$ & na \\
\hline MSA Population & na & $\begin{array}{c}1,066,035 \\
(1,368,963)\end{array}$ & $\begin{array}{c}690,613 \\
(1,330,991)\end{array}$ & $\begin{array}{c}1,345,398 \\
(1,330,919)\end{array}$ \\
\hline Nonmetro County Population & $\begin{array}{c}23,291 \\
(22,776)\end{array}$ & na & na & na \\
\hline \multicolumn{5}{|l|}{ Economic Development: } \\
\hline 1980-90 Ind. Structural Changed (ISC) & $\begin{array}{c}0.107 \\
(0.043)\end{array}$ & $\begin{array}{c}0.105 \\
(0.035)\end{array}$ & $\begin{array}{c}0.091 \\
(0.025)\end{array}$ & $\begin{array}{c}0.115 \\
(0.038)\end{array}$ \\
\hline 1985-90 Ind. Structural Changed (ISC) & $\begin{array}{c}0.067 \\
(0.032)\end{array}$ & $\begin{array}{c}0.057 \\
(0.022)\end{array}$ & $\begin{array}{c}0.048 \\
(0.015)\end{array}$ & $\begin{array}{c}0.063 \\
(0.024)\end{array}$ \\
\hline 1988-90 Ind. Structural Changed (ISC) & $\begin{array}{c}0.036 \\
(0.013)\end{array}$ & $\begin{array}{c}0.028 \\
(0.009)\end{array}$ & $\begin{array}{c}0.022 \\
(0.015)\end{array}$ & $\begin{array}{c}0.032 \\
(0.019)\end{array}$ \\
\hline Log Average Family Income & $\begin{array}{l}10.33 \\
(0.16)\end{array}$ & $\begin{array}{l}10.63 \\
(0.21)\end{array}$ & $\begin{array}{l}10.61 \\
(0.16)\end{array}$ & $\begin{array}{l}10.64 \\
(0.23)\end{array}$ \\
\hline 1980-90 Employment Growthe & $\begin{array}{c}0.16 \\
(0.34)\end{array}$ & $\begin{array}{c}0.40 \\
(0.44)\end{array}$ & $\begin{array}{c}0.27 \\
(0.25)\end{array}$ & $\begin{array}{c}0.49 \\
(0.52)\end{array}$ \\
\hline 1988-90 Employment Growthe & $\begin{array}{c}0.07 \\
(0.13)\end{array}$ & $\begin{array}{c}0.09 \\
(0.09)\end{array}$ & $\begin{array}{c}0.07 \\
(0.06)\end{array}$ & $\begin{array}{c}0.10 \\
(0.11)\end{array}$ \\
\hline \%Civ. Female Labor Force Participation & $\begin{array}{l}50.24 \\
(6.54)\end{array}$ & $\begin{array}{l}57.25 \\
(6.16)\end{array}$ & $\begin{array}{l}56.70 \\
(5.30)\end{array}$ & $\begin{array}{l}57.66 \\
(6.70)\end{array}$ \\
\hline \%Civ. Male Labor Force Participation & $\begin{array}{l}69.0 \\
(7.1)\end{array}$ & $\begin{array}{l}74.63 \\
(5.80)\end{array}$ & $\begin{array}{l}73.36 \\
(4.74)\end{array}$ & $\begin{array}{l}75.57 \\
(6.32)\end{array}$ \\
\hline \%Union in State & $\begin{array}{l}12.8 \\
(5.7)\end{array}$ & $\begin{array}{l}14.7 \\
(6.8)\end{array}$ & $\begin{array}{l}15.2 \\
(6.8)\end{array}$ & $\begin{array}{l}14.3 \\
(6.7)\end{array}$ \\
\hline \%Income from Self-Employment & $\begin{array}{c}6.74 \\
(2.26)\end{array}$ & $\begin{array}{c}5.6 \\
(1.5)\end{array}$ & $\begin{array}{c}5.75 \\
(1.49)\end{array}$ & $\begin{array}{l}5.46 \\
(1.53)\end{array}$ \\
\hline $\begin{array}{l}\text { Industry Composition: } \\
\% \text { Agriculture, Forest, Fisheries }\end{array}$ & $\begin{array}{l}10.56 \\
(9.28)\end{array}$ & $\begin{array}{c}2.62 \\
(2.30)\end{array}$ & $\begin{array}{c}2.30 \\
(2.34)\end{array}$ & $\begin{array}{c}2.86 \\
(2.24)\end{array}$ \\
\hline$\%$ Mining & $\begin{array}{c}2.12 \\
(4.41)\end{array}$ & $\begin{array}{c}0.61 \\
(1.38)\end{array}$ & $\begin{array}{c}0.61 \\
(1.67)\end{array}$ & $\begin{array}{l}0.61 \\
(1.16)\end{array}$ \\
\hline$\%$ Construction & $\begin{array}{l}6.89 \\
(2.36)\end{array}$ & $\begin{array}{c}6.74 \\
(2.03)\end{array}$ & $\begin{array}{l}5.93 \\
(1.49)\end{array}$ & $\begin{array}{l}7.35 \\
(2.16)\end{array}$ \\
\hline
\end{tabular}


TABLE 2 (continued)

Descriptive Statistics

\begin{tabular}{|c|c|c|c|c|}
\hline Variable & $\begin{array}{c}\text { Nonmetro } \\
\text { Counties } \\
\text { (std. dev.) } \\
\text { (1) }\end{array}$ & $\begin{array}{c}\text { Metro } \\
\text { Counties } \\
\text { (std. dev.) } \\
(2)\end{array}$ & $\begin{array}{l}\text { Central City } \\
\text { Counties } \\
\text { (std. dev.) } \\
\text { (3) }\end{array}$ & $\begin{array}{c}\text { Suburban } \\
\text { Counties } \\
\text { (std. dev.) } \\
\text { (4) }\end{array}$ \\
\hline \%Nondurable Manufacturing & $\begin{array}{c}8.32 \\
(6.73)\end{array}$ & $\begin{array}{c}7.60 \\
(4.54)\end{array}$ & $\begin{array}{c}6.71 \\
(3.68)\end{array}$ & $\begin{array}{c}8.26 \\
(5.00)\end{array}$ \\
\hline$\%$ Durable Manufacturing & $\begin{array}{l}10.22 \\
(7.16)\end{array}$ & $\begin{array}{l}11.12 \\
(5.93)\end{array}$ & $\begin{array}{l}10.16 \\
(5.97)\end{array}$ & $\begin{array}{l}11.83 \\
(5.80)\end{array}$ \\
\hline$\%$ Communications & $\begin{array}{c}2.43 \\
(1.46)\end{array}$ & $\begin{array}{c}2.76 \\
(0.98)\end{array}$ & $\begin{array}{c}2.64 \\
(0.82)\end{array}$ & $\begin{array}{c}2.85 \\
(1.08)\end{array}$ \\
\hline$\%$ Transportation & $\begin{array}{c}3.90 \\
(1.45)\end{array}$ & $\begin{array}{c}4.37 \\
(1.67)\end{array}$ & $\begin{array}{c}4.08 \\
(1.29)\end{array}$ & $\begin{array}{c}4.58 \\
(1.88)\end{array}$ \\
\hline$\%$ Trade & $\begin{array}{l}19.01 \\
(3.55)\end{array}$ & $\begin{array}{l}21.52 \\
(2.49)\end{array}$ & $\begin{array}{l}22.29 \\
(2.31)\end{array}$ & $\begin{array}{l}20.94 \\
(2.46)\end{array}$ \\
\hline$\%$ FIRE & $\begin{array}{c}3.81 \\
(1.26)\end{array}$ & $\begin{array}{c}6.11 \\
(2.15)\end{array}$ & $\begin{array}{c}6.35 \\
(2.19)\end{array}$ & $\begin{array}{c}5.93 \\
(2.10)\end{array}$ \\
\hline$\%$ Entertainment Services & $\begin{array}{c}0.89 \\
(0.80)\end{array}$ & $\begin{array}{c}1.23 \\
(0.90)\end{array}$ & $\begin{array}{c}1.40 \\
(1.10)\end{array}$ & $\begin{array}{c}1.11 \\
(0.69)\end{array}$ \\
\hline$\%$ Health Services & $\begin{array}{c}7.68 \\
(3.13)\end{array}$ & $\begin{array}{c}8.52 \\
(2.68)\end{array}$ & $\begin{array}{c}9.33 \\
(2.86)\end{array}$ & $\begin{array}{c}7.92 \\
(2.38)\end{array}$ \\
\hline \%Professional Services & $\begin{array}{c}4.51 \\
(1.43)\end{array}$ & $\begin{array}{c}6.07 \\
(2.50)\end{array}$ & $\begin{array}{c}6.46 \\
(1.61)\end{array}$ & $\begin{array}{c}5.78 \\
(2.97)\end{array}$ \\
\hline$\%$ Personal Services & $\begin{array}{c}3.10 \\
(1.66)\end{array}$ & $\begin{array}{c}2.95 \\
(1.19)\end{array}$ & $\begin{array}{c}3.26 \\
(1.39)\end{array}$ & $\begin{array}{c}2.71 \\
(0.96)\end{array}$ \\
\hline \%Business Services & $\begin{array}{c}3.03 \\
(0.92)\end{array}$ & $\begin{array}{c}4.37 \\
(1.05)\end{array}$ & $\begin{array}{c}4.51 \\
(0.96)\end{array}$ & $\begin{array}{c}4.27 \\
(1.11)\end{array}$ \\
\hline \%Educational Services & $\begin{array}{c}9.02 \\
(3.43)\end{array}$ & $\begin{array}{c}8.52 \\
(3.20)\end{array}$ & $\begin{array}{c}9.28 \\
(3.69)\end{array}$ & $\begin{array}{c}7.95 \\
(2.65)\end{array}$ \\
\hline \%Public Administration & $\begin{array}{c}4.75 \\
(2.85)\end{array}$ & $\begin{array}{c}5.08 \\
(3.31)\end{array}$ & $\begin{array}{c}4.90 \\
(2.90)\end{array}$ & $\begin{array}{c}5.21 \\
(3.58)\end{array}$ \\
\hline $\begin{array}{l}\text { Human K/Demographic: } \\
\% \text { High School Graduate/Some College }\end{array}$ & & & & 57.22 \\
\hline \%Hign scnool Graauate/some College & $\begin{array}{l}55.86 \\
(7.94)\end{array}$ & $\begin{array}{l}56.11 \\
(6.13)\end{array}$ & $\begin{array}{l}56.01 \\
(5.78)\end{array}$ & $(6.34)$ \\
\hline$\% 4$-Year College Graduate & $\begin{array}{l}11.81 \\
(4.87)\end{array}$ & $\begin{array}{l}18.76 \\
(8.25)\end{array}$ & $\begin{array}{l}20.28 \\
(6.68)\end{array}$ & $\begin{array}{l}17.63 \\
(9.10)\end{array}$ \\
\hline Education Standard Deviation $\mathrm{f}$ & $\begin{array}{c}2.99 \\
(0.28)\end{array}$ & $\begin{array}{c}2.96 \\
(0.26)\end{array}$ & $\begin{array}{c}3.02 \\
(0.26)\end{array}$ & $\begin{array}{c}2.91 \\
(0.24)\end{array}$ \\
\hline$\%$ Female-Headed Family & $\begin{array}{l}12.29 \\
(5.46)\end{array}$ & $\begin{array}{l}14.34 \\
(4.75)\end{array}$ & $\begin{array}{l}16.64 \\
(4.98)\end{array}$ & $\begin{array}{l}12.63 \\
(3.75)\end{array}$ \\
\hline$\% 18-24$ years old & $\begin{array}{c}8.70 \\
(3.56)\end{array}$ & $\begin{array}{l}10.65 \\
(3.53)\end{array}$ & $\begin{array}{l}11.49 \\
(3.75)\end{array}$ & $\begin{array}{l}10.03 \\
(3.23)\end{array}$ \\
\hline$\% 60-64$ years old & $\begin{array}{c}4.87 \\
(0.98)\end{array}$ & $\begin{array}{c}4.18 \\
(0.84)\end{array}$ & $\begin{array}{c}4.22 \\
(0.79)\end{array}$ & $\begin{array}{c}4.14 \\
(0.87)\end{array}$ \\
\hline$\% 65$ and over & $\begin{array}{l}15.90 \\
(4.17)\end{array}$ & $\begin{array}{l}11.90 \\
(3.45)\end{array}$ & $\begin{array}{l}12.46 \\
(3.36)\end{array}$ & $\begin{array}{l}11.49 \\
(3.46)\end{array}$ \\
\hline Average Children Per Family & $\begin{array}{c}0.91 \\
(0.15)\end{array}$ & $\begin{array}{c}0.90 \\
(0.13)\end{array}$ & $\begin{array}{c}0.90 \\
(0.13)\end{array}$ & $\begin{array}{c}0.89 \\
(0.13)\end{array}$ \\
\hline \%Same County in 1985 & $\begin{array}{l}80.86 \\
(7.63)\end{array}$ & $\begin{array}{l}76.33 \\
(9.16)\end{array}$ & $\begin{array}{l}78.44 \\
(7.94)\end{array}$ & $\begin{array}{l}74.76 \\
(9.68)\end{array}$ \\
\hline$\%$ African-American & $\begin{array}{c}8.24 \\
(15.1)\end{array}$ & $\begin{array}{c}9.86 \\
(11.7)\end{array}$ & $\begin{array}{c}11.97 \\
(12.21)\end{array}$ & $\begin{array}{c}8.29 \\
(11.11)\end{array}$ \\
\hline$\%$ Non-African-American Minority & $\begin{array}{l}3.86 \\
(8.3)\end{array}$ & $\begin{array}{l}4.04 \\
(5.5)\end{array}$ & $\begin{array}{c}5.80 \\
(6.85)\end{array}$ & $\begin{array}{c}2.72 \\
(3.66)\end{array}$ \\
\hline$\% 1985-90$ Foreign Immigrants & $\begin{array}{c}0.34 \\
(0.71)\end{array}$ & $\begin{array}{c}0.93 \\
(1.43)\end{array}$ & $\begin{array}{c}1.33 \\
(1.71)\end{array}$ & $\begin{array}{c}0.62 \\
(1.09)\end{array}$ \\
\hline West & $\begin{array}{c}0.14 \\
(0.35)\end{array}$ & $\begin{array}{c}0.11 \\
(0.31)\end{array}$ & $\begin{array}{c}0.18 \\
(0.38)\end{array}$ & $\begin{array}{c}0.05 \\
(0.22)\end{array}$ \\
\hline
\end{tabular}


TABLE 2 (continued)

Descriptive Statistics

\begin{tabular}{lcccc}
\hline Variable & $\begin{array}{c}\text { Nonmetro } \\
\text { Counties } \\
\text { (std. dev.) } \\
(1)\end{array}$ & $\begin{array}{c}\text { Metro } \\
\text { Counties } \\
\text { (std. dev.) } \\
(2)\end{array}$ & $\begin{array}{c}\text { Central City } \\
\text { Counties } \\
\text { (std. dev.) } \\
(3)\end{array}$ & $\begin{array}{c}\text { Suburban } \\
\text { Counties } \\
\text { (std. dev.) } \\
(4)\end{array}$ \\
\hline Midwest & 0.36 & 0.27 & 0.27 & 0.26 \\
South & $(0.48)$ & $(0.44)$ & $(0.44)$ & $(0.44)$ \\
& 0.45 & 0.47 & 0.38 & 0.54 \\
Northeast & $(0.50)$ & $(0.50)$ & $(0.49)$ & $(0.50)$ \\
& 0.08 & 0.17 & 0.18 & 0.16 \\
N & $(0.27)$ & $(0.37)$ & $(0.38)$ & $(0.36)$ \\
\hline
\end{tabular}

aSuburban MSA counties are defined as all counties in a multiple-county MSA that do not contain the largest city in the metropolitan area. A small MSA is defined as a total MSA population of less than 350,000 .

buburban MSA counties are defined as all counties in a multiple-county MSA that do not contain the largest city in the metropolitan area. A large MSA is defined as a total MSA population of greater than 350,000 .

cA central city MSA county is defined as the county containing the largest city in a multicounty MSA. For this table, single-county MSAs also are included in the central city category.

dThe sample size for the ISC variables was reduced by 86 using the 90 percent criterion described in the Data Appendix (8 metro, 78 nonmetro).

eChange in employment during the time span divided by the beginning of the period level of employment, or the employment growth ratio.

The standard deviation in years of education.

Regarding how these variations in characteristics explain income inequality differences, we turn to the regression results shown in Table 3. The regression specification we use assumes a linear form of equation (1) and adds an error term. As described in the Data Appendix, nondisclosure problems in constructing the ISC variables required the omission of 86 counties. ${ }^{16}$ Columns (1)-(4) contain the results for metro counties, while columns (5)-(8) contain the results for nonmetro counties. For both metro counties and nonmetro counties, we use the Gini coefficient and the variance of the log of income as the dependent variable. In sensitivity analysis, industry composition variables are omitted from the metro regressions with results shown in columns (3) and (4) and from the nonmetro regressions with results shown in columns (7) and (8). ${ }^{17}$

We first examine the metro results. The coefficient patterns and t-statistics in columns (1) and (3) for the Gini are very similar to those of the variance of the log of income in columns (2) and (4). Because the variance and the Gini emphasize different segments of the income distribution, this similarity suggests that our findings are generally robust to the particular measure of income inequality used. For brevity, we primarily focus on the results based on the Gini coefficient as the dependent variable.

\footnotetext{
${ }^{16}$ There is no reason to suspect that there was anything systematic about these 86 counties. The descriptive statistics were virtually the same in the entire sample of 3,109 counties as in the subsample of 3,023 counties. ${ }^{17} \mathrm{We}$ also estimated White-heteroscedasticity corrected t-statistics, but they were essentially the same as the reported OLS estimates. Note that in the following discussion we assume a normal distribution for the regression coefficients. As shown in Greene (1997, pp. 276-277), this is always true asymptotically regardless of whether the dependent variable or the residual is distributed normally. Thus, with the large sample sizes in our regressions, our hypothesis tests should be reasonably accurate.
} 


\section{TABLE 3}

Metro/Nonmetro Regression Results

(absolute value of $\mathrm{t}$-statistics)

\begin{tabular}{|c|c|c|c|c|c|c|c|c|}
\hline Variable & $\begin{array}{c}\text { Gini } \times 100 \mathrm{~V} \\
\text { Metro } \\
(1)\end{array}$ & $\begin{array}{l}\text { Var x } 100 \\
\text { Metro } \\
(2)\end{array}$ & $\begin{array}{c}\text { Gini x } 100 \mathrm{~V} \\
\text { Metro } \\
(3)\end{array}$ & $\begin{array}{c}\text { Var x } 100 \\
\text { Metro } \\
(4)\end{array}$ & $\begin{array}{c}\text { Gini x } 100 \\
\text { Nonmetro } \\
(5)\end{array}$ & $\begin{array}{c}\text { Var x } 100 \\
\text { Nonmetro } \\
(6)\end{array}$ & $\begin{array}{c}\text { Gini x } 100 \\
\text { Nonmetro } \\
(7)\end{array}$ & $\begin{array}{c}\text { Var x } 100 \\
\text { Nonmetro } \\
(8)\end{array}$ \\
\hline \multicolumn{9}{|l|}{ Metro/Nonmetro: } \\
\hline Single-County MSA & na & na & na & na & na & na & na & na \\
\hline Small-MSA Suburban County & $-0.65^{* *}$ & $-1.91^{*}$ & $-0.65^{* *}$ & $-1.58^{*}$ & na & na & na & na \\
\hline & $(2.81)$ & $(2.37)$ & $(2.82)$ & (1.99) & na & na & na & na \\
\hline Large-MSA Suburban County & $\begin{array}{l}-0.47^{*} \\
(2.46)\end{array}$ & $\begin{array}{l}-1.68^{*} \\
(2.51)\end{array}$ & $\begin{array}{l}-0.46^{*} \\
(2.39)\end{array}$ & $\begin{array}{l}-1.48^{*} \\
(2.20)\end{array}$ & na & na & na & na \\
\hline Central City County & $\begin{array}{c}0.18 \\
(0.97)\end{array}$ & $\begin{array}{c}0.62 \\
(0.98)\end{array}$ & $\begin{array}{c}0.16 \\
(0.88)\end{array}$ & $\begin{array}{c}0.56 \\
(0.88)\end{array}$ & na & na & na & na \\
\hline MSA Population & $\begin{array}{l}-2.1 \mathrm{E}-7^{* *} \\
(3.27)\end{array}$ & $\begin{aligned} * & -4.0 \mathrm{E}-7 \\
& (1.81)\end{aligned}$ & $\begin{array}{l}-2.8 \mathrm{E}-7^{* *} \\
(4.45)\end{array}$ & $\begin{array}{l}-4.4 \mathrm{E}-7^{*} \\
(2.06)\end{array}$ & na & na & na & na \\
\hline Nonmetro County Population & na & na & na & na & $\begin{array}{c}5.0 \mathrm{E}-6 \\
(1.71)\end{array}$ & $\begin{array}{l}1.7 \mathrm{E}-5 \\
(1.91)\end{array}$ & $\begin{array}{c}-1.6 \mathrm{E}-6 \\
(0.54)\end{array}$ & $\begin{array}{c}2.4 \mathrm{E}-6 \\
(0.27)\end{array}$ \\
\hline \multicolumn{9}{|l|}{ Economic Development: } \\
\hline $1988-90$ ISC & $\begin{array}{c}9.14 \\
(1.93)\end{array}$ & $\begin{array}{l}31.68 \\
(1.91)\end{array}$ & $\begin{array}{l}11.87^{*} \\
(2.46)\end{array}$ & $\begin{array}{l}44.14^{* *} \\
(2.64)\end{array}$ & & & & \\
\hline $1985-90$ ISC & & & & & $\begin{array}{l}3.42^{*} \\
(2.14)\end{array}$ & $\begin{array}{c}2.22 \\
(0.45)\end{array}$ & $\begin{array}{c}2.90 \\
(1.67)\end{array}$ & $\begin{array}{c}5.54 \\
(1.08)\end{array}$ \\
\hline Log Avg. Family Income & $\begin{array}{l}7.21^{* *} \\
(7.58)\end{array}$ & $\begin{array}{l}19.17^{* *} \\
(5.73)\end{array}$ & $\begin{array}{l}7.30^{* *} \\
(8.31)\end{array}$ & $\begin{array}{l}20.43^{* *} \\
(6.72)\end{array}$ & $\begin{array}{l}10.65^{* *} \\
(16.83)\end{array}$ & $\begin{array}{c}17.83^{* * *} \\
(9.10)\end{array}$ & $\begin{array}{l}7.49 * * \\
(11.64)\end{array}$ & $\begin{array}{c}11.61^{* *} \\
(6.09)\end{array}$ \\
\hline 1980-90 Employ. Growth & $\begin{array}{l}-0.07 \\
(0.34)\end{array}$ & $\begin{array}{l}-0.81 \\
(1.18)\end{array}$ & $\begin{array}{c}0.10 \\
(0.51)\end{array}$ & $\begin{array}{l}-0.39 \\
(0.57)\end{array}$ & $\begin{array}{c}0.15 \\
(0.87)\end{array}$ & $\begin{array}{c}0.13 \\
(0.25)\end{array}$ & $\begin{array}{c}0.17 \\
(0.96)\end{array}$ & $\begin{array}{c}-0.10 \\
(0.18)\end{array}$ \\
\hline 1988-90 Employ. Growth & $\begin{array}{l}-0.32 \\
(0.47)\end{array}$ & $\begin{array}{l}-0.06 \\
(0.03)\end{array}$ & $\begin{array}{l}-0.94 \\
(1.32)\end{array}$ & $\begin{array}{l}-1.63 \\
(0.66)\end{array}$ & $\begin{array}{c}-0.60 \\
(1.54)\end{array}$ & $\begin{array}{l}-1.97 \\
(1.62)\end{array}$ & $\begin{array}{c}-0.46 \\
(1.07)\end{array}$ & (1.13) \\
\hline$\%$ Civ. Fem LF Participation & $\begin{array}{c}-0.34^{* *} \\
(14.55)\end{array}$ & $\begin{array}{c}-1.30^{* *} \\
(15.72)\end{array}$ & $\begin{array}{c}-0.34^{* *} \\
(14.78)\end{array}$ & $\begin{array}{c}-1.31^{* *} \\
(16.50)\end{array}$ & $\begin{array}{l}-0.23^{* *} \\
(14.82)\end{array}$ & $\begin{array}{l}-0.75^{* *} \\
(15.48)\end{array}$ & $\begin{array}{l}-0.25^{* *} \\
(16.73)\end{array}$ & $\begin{array}{c}-0.87^{* *} \\
(19.82)\end{array}$ \\
\hline \%Civ. Male LF Participation & $\begin{array}{l}-0.04^{*} \\
(2.05)\end{array}$ & $\begin{array}{l}-0.08 \\
(1.04)\end{array}$ & $\begin{array}{l}-0.006 \\
(0.27)\end{array}$ & $\begin{array}{c}0.02 \\
(0.31)\end{array}$ & $\begin{array}{l}-0.10^{* *} \\
(7.10)\end{array}$ & $\begin{array}{l}-0.21^{* *} \\
(5.03)\end{array}$ & $\begin{array}{c}-0.02 \\
(1.90)\end{array}$ & $\begin{array}{r}-0.04 \\
(1.06)\end{array}$ \\
\hline \%Income from Self-Emp. & $\begin{array}{c}0.83^{* *} \\
(15.32)\end{array}$ & $\begin{array}{l}1.75^{* *} \\
(9.22)\end{array}$ & $\begin{array}{c}0.96^{* *} \\
(18.94)\end{array}$ & $\begin{array}{c}2.07^{* *} \\
(11.79)\end{array}$ & $\begin{array}{c}0.27^{* *} \\
(10.85)\end{array}$ & $\begin{array}{c}0.15 \\
(1.94)\end{array}$ & $\begin{array}{c}0.34^{* *} \\
(13.10)\end{array}$ & $\begin{array}{l}0.28^{* *} \\
(3.65)\end{array}$ \\
\hline Industry Composition: & & & & & & & & \\
\hline$\%$ Agric., Forest, Fisheries & $\begin{array}{l}0.24^{* *} \\
(5.74)\end{array}$ & $\begin{array}{l}0.61^{* *} \\
(4.08)\end{array}$ & & & $\begin{array}{c}0.23^{* *} \\
(10.90)\end{array}$ & $\begin{array}{l}0.57^{* *} \\
(8.63)\end{array}$ & & \\
\hline \%Mining & $\begin{array}{c}0.08 \\
(1.53)\end{array}$ & $\begin{array}{c}0.33 \\
(1.79)\end{array}$ & & & $\begin{array}{l}0.007 \\
(0.31)\end{array}$ & $\begin{array}{l}0.18^{*} \\
(2.48)\end{array}$ & & \\
\hline$\%$ Construction & $\begin{array}{c}0.04 \\
(0.71)\end{array}$ & $\begin{array}{r}0.44^{*} \\
(2.46)\end{array}$ & & & $\begin{array}{l}0.07^{*} \\
(2.21)\end{array}$ & $\begin{array}{c}0.19 \\
(1.90)\end{array}$ & & \\
\hline$\%$ Nondurable Manufacturing & $\begin{array}{l}0.07^{* *} \\
(2.68)\end{array}$ & $\begin{array}{l}0.18^{*} \\
(2.11)\end{array}$ & & & $\begin{array}{l}0.05^{*} \\
(2.44)\end{array}$ & $\begin{array}{l}0.16^{*} \\
(2.47)\end{array}$ & & \\
\hline$\%$ Durable Manufacturing & $\begin{array}{l}0.06^{* *} \\
(2.75)\end{array}$ & $\begin{array}{r}0.18^{*} \\
(2.29)\end{array}$ & & & $\begin{array}{l}0.04^{*} \\
(2.28)\end{array}$ & $\begin{array}{l}0.14^{*} \\
(2.38)\end{array}$ & & \\
\hline$\%$ Communications & $\begin{array}{c}0.02 \\
(0.36)\end{array}$ & $\begin{array}{l}-0.04 \\
(0.16)\end{array}$ & & & $\begin{array}{c}0.03 \\
(0.65)\end{array}$ & $\begin{array}{l}0.52^{* *} \\
(4.09)\end{array}$ & & \\
\hline$\%$ Transportation & $\begin{array}{l}-0.004 \\
(0.09)\end{array}$ & $\begin{array}{l}-0.08 \\
(0.50)\end{array}$ & & & $\begin{array}{l}0.13^{* *} \\
(3.30)\end{array}$ & $\begin{array}{l}0.55^{* *} \\
(4.50)\end{array}$ & & \\
\hline$\%$ Trade & $\begin{array}{l}0.13^{* *} \\
(3.68)\end{array}$ & $\begin{array}{c}0.14 \\
(1.17)\end{array}$ & & & $\begin{array}{l}0.14^{* *} \\
(5.46)\end{array}$ & $\begin{array}{l}0.31^{* *} \\
(4.02)\end{array}$ & & \\
\hline \%FIRE & $\begin{array}{c}0.06 \\
(1.33)\end{array}$ & $\begin{array}{c}0.15 \\
(0.97)\end{array}$ & & & $\begin{array}{c}0.07 \\
(1.48)\end{array}$ & $\begin{array}{c}0.28 \\
(1.79)\end{array}$ & & \\
\hline \%Entertainment Services & $\begin{array}{c}0.05 \\
(0.44)\end{array}$ & $\begin{array}{c}0.64 \\
(1.72)\end{array}$ & & & $\begin{array}{l}0.25^{* *} \\
(3.15)\end{array}$ & $\begin{array}{c}-0.13 \\
(0.52)\end{array}$ & & \\
\hline \%Health Services & $\begin{array}{l}-0.05 \\
(1.68)\end{array}$ & $\begin{array}{l}-0.29 * * \\
(2.87)\end{array}$ & & & $\begin{array}{l}0.05^{*} \\
(2.30)\end{array}$ & $\begin{array}{l}0.19^{* *} \\
(2.67)\end{array}$ & & \\
\hline \%Professional Services & $\begin{array}{l}-0.07 \\
(1.45)\end{array}$ & $\begin{array}{c}0.06 \\
(0.39)\end{array}$ & & & $\begin{array}{c}0.07 \\
(1.48)\end{array}$ & $\begin{array}{c}0.10 \\
(0.64)\end{array}$ & & \\
\hline$\%$ Personal Services & $\begin{array}{l}0.23^{*} \\
(2.56)\end{array}$ & $\begin{array}{c}0.08 \\
(0.25)\end{array}$ & & & $\begin{array}{l}0.30^{* * *} \\
(7.64)\end{array}$ & $\begin{array}{l}0.92^{* *} \\
(7.46)\end{array}$ & & \\
\hline $\begin{array}{l}\text { \%Business Services } \\
(0.69)\end{array}$ & $\begin{array}{c}0.06 \\
(1.32)\end{array}$ & 0.43 & & & $\begin{array}{l}0.21^{* *} \\
(3.40)\end{array}$ & $\begin{array}{l}0.68^{* *} \\
(3.60)\end{array}$ & & \\
\hline \%Educational Services & $\begin{array}{c}0.01 \\
(0.25)\end{array}$ & $\begin{array}{c}0.29 \\
(1.95)\end{array}$ & & & $\begin{array}{l}0.14^{* *} \\
(4.59)\end{array}$ & $\begin{array}{l}0.45^{* *} \\
(4.71)\end{array}$ & & \\
\hline
\end{tabular}


TABLE 3 (continued)

Metro/Nonmetro Regression Results

(absolute value of $\mathrm{t}$-statistics)

\begin{tabular}{|c|c|c|c|c|c|c|c|c|}
\hline Variable & $\begin{array}{l}\text { Gini x } 100 \\
\text { Metro } \\
\text { (1) }\end{array}$ & $\begin{array}{c}\text { Var x } 100 \\
\text { Metro } \\
\text { (2) }\end{array}$ & $\begin{array}{l}\text { Gini } \times 100 \\
\text { Metro } \\
\text { (3) }\end{array}$ & $\begin{array}{c}\text { Var } \times 100 \\
\text { Metro } \\
(4)\end{array}$ & $\begin{array}{c}\text { Gini } \times 100 \\
\text { Nonmetro } \\
(5)\end{array}$ & $\begin{array}{c}\text { Var x } 100 \\
\text { Nonmetro } \\
(6)\end{array}$ & $\begin{array}{c}\text { Gini } \times 100 \\
\text { Nonmetro } \\
(7)\end{array}$ & $\begin{array}{c}\text { Var } \times 100 \\
\text { Nonmetro } \\
(8)\end{array}$ \\
\hline $\begin{array}{l}\text { \%Public Administration } \\
\text { Human K/Demographic: }\end{array}$ & na & na & & & na & na & & \\
\hline$\%$ HS Graduate/Some College & $\begin{array}{c}0.03 \\
(0.88)\end{array}$ & $\begin{array}{l}0.34^{* *} \\
(3.34)\end{array}$ & $\begin{array}{c}0.009 \\
(0.36)\end{array}$ & $\begin{array}{c}0.16 \\
(1.81)\end{array}$ & $\begin{array}{l}-0.20^{* *} \\
(10.97)\end{array}$ & $\begin{array}{l}-0.28^{* *} \\
(5.02)\end{array}$ & $\begin{array}{l}-0.17^{* *} \\
(9.24)\end{array}$ & $\begin{array}{l}-0.22^{* *} \\
(4.00)\end{array}$ \\
\hline$\% 4$-Year College Graduate & $\begin{array}{l}0.06^{*} \\
(2.12)\end{array}$ & $\begin{array}{c}0.18 \\
(1.77)\end{array}$ & $\begin{array}{l}-0.01 \\
(0.62)\end{array}$ & $\begin{array}{l}-0.005 \\
(0.07)\end{array}$ & $\begin{array}{l}-0.07^{* *} \\
(3.10)\end{array}$ & $\begin{array}{c}0.09 \\
(1.21)\end{array}$ & $\begin{array}{c}0.02 \\
(1.09)\end{array}$ & $\begin{array}{l}0.30^{* *} \\
(4.97)\end{array}$ \\
\hline Education Standard Deviation & $\begin{array}{l}3.15^{* *} \\
(5.29)\end{array}$ & $\begin{array}{l}13.95^{* *} \\
(6.66)\end{array}$ & $\begin{array}{l}3.53^{* *} \\
(6.46)\end{array}$ & $\begin{array}{l}14.07^{* *} \\
(7.43)\end{array}$ & $\begin{array}{l}0.08 \\
(0.20)\end{array}$ & $\begin{array}{l}4.38^{* *} \\
(3.56)\end{array}$ & $\begin{array}{l}0.85^{*} \\
(2.03)\end{array}$ & $\begin{array}{l}6.13^{* *} \\
(4.96)\end{array}$ \\
\hline \%Female-Headed Family & $\begin{array}{c}0.52^{* *} \\
(15.29)\end{array}$ & $\begin{array}{c}2.32^{* *} \\
(19.33)\end{array}$ & $\begin{array}{l}0.47^{* *} \\
(15.37)\end{array}$ & $\begin{array}{c}2.11^{* *} \\
(19.94)\end{array}$ & $\begin{array}{c}0.40^{* *} \\
(18.47)\end{array}$ & $\begin{array}{c}1.36^{* *} \\
(20.11)\end{array}$ & $\begin{array}{c}0.32^{* *} \\
(14.19)\end{array}$ & $\begin{array}{c}1.17^{* *} \\
(17.60)\end{array}$ \\
\hline$\% 18-24$ years old & $\begin{array}{l}-0.02 \\
(0.59)\end{array}$ & $\begin{array}{l}-0.46^{* *} \\
(3.51)\end{array}$ & $\begin{array}{c}0.01 \\
(0.42)\end{array}$ & $\begin{array}{l}-0.25^{*} \\
(2.51)\end{array}$ & $\begin{array}{l}-0.04 \\
(1.53)\end{array}$ & $\begin{array}{l}-0.16 \\
(1.93)\end{array}$ & $\begin{array}{l}-0.01 \\
(0.50)\end{array}$ & $\begin{array}{l}-0.09 \\
(1.31)\end{array}$ \\
\hline$\% 60-64$ years old & $\begin{array}{l}-0.04 \\
(0.18)\end{array}$ & $\begin{array}{l}-0.42 \\
(0.62)\end{array}$ & $\begin{array}{l}-0.03 \\
(0.13)\end{array}$ & $\begin{array}{l}-0.65 \\
(0.95)\end{array}$ & $\begin{array}{l}-0.13 \\
(1.50)\end{array}$ & $\begin{array}{l}-0.85^{* *} \\
(3.11)\end{array}$ & $\begin{array}{l}0.23^{*} \\
(2.47)\end{array}$ & $\begin{array}{l}-0.20 \\
(0.72)\end{array}$ \\
\hline$\% 65$ and over & $\begin{array}{l}-0.14^{* *} \\
(3.15)\end{array}$ & $\begin{array}{l}-1.08^{* *} \\
(6.86)\end{array}$ & $\begin{array}{l}-0.07 \\
(1.63)\end{array}$ & $\begin{array}{l}-0.94^{* *} \\
(6.30)\end{array}$ & $\begin{array}{l}-0.14^{* *} \\
(5.30)\end{array}$ & $\begin{array}{c}-0.84^{* *} \\
(10.17)\end{array}$ & $\begin{array}{l}-0.07^{* *} \\
(2.61)\end{array}$ & $\begin{array}{l}-0.73^{* *} \\
(8.97)\end{array}$ \\
\hline Avg. Children Per Family & $\begin{array}{l}-2.58^{*} \\
(2.27)\end{array}$ & $\begin{array}{c}-14.42^{* *} \\
(3.60)\end{array}$ & $\begin{array}{l}-1.58 \\
(1.42)\end{array}$ & $\begin{array}{c}-11.93^{* *} \\
(3.10)\end{array}$ & $\begin{array}{l}-1.30 \\
(1.75)\end{array}$ & $\begin{array}{l}-9.86^{* *} \\
(4.30)\end{array}$ & $\begin{array}{c}0.47 \\
(0.59)\end{array}$ & $\begin{array}{l}-5.39^{*} \\
(2.29)\end{array}$ \\
\hline \%Same County in 1985 & $\begin{array}{c}0.02 \\
(1.14)\end{array}$ & $\begin{array}{c}0.06 \\
(1.07)\end{array}$ & $\begin{array}{l}0.01 \\
(0.80)\end{array}$ & $\begin{array}{c}0.04 \\
(0.86)\end{array}$ & $\begin{aligned} 0.03^{*} \\
(2.37)\end{aligned}$ & $\begin{array}{l}0.14^{* *} \\
(3.75)\end{array}$ & $\begin{array}{c}0.02 \\
(1.70)\end{array}$ & $\begin{array}{l}0.14^{* *} \\
(3.76)\end{array}$ \\
\hline$\%$ African-American & $\begin{array}{l}-0.02 \\
(1.94)\end{array}$ & $\begin{array}{l}-0.01 \\
(0.31)\end{array}$ & $\begin{array}{l}-0.01 \\
(1.23)\end{array}$ & $\begin{array}{l}-5.7 \mathrm{E}-4 \\
(0.02)\end{array}$ & $\begin{array}{l}-0.03^{* *} \\
(3.36)\end{array}$ & $\begin{array}{c}0.02 \\
(0.83)\end{array}$ & $\begin{array}{c}0.01 \\
(1.51)\end{array}$ & $\begin{array}{l}0.10^{* *} \\
(4.11)\end{array}$ \\
\hline \%Non-Afr.-Amer. Minority & $\begin{array}{l}0.04 \\
(1.61)\end{array}$ & $\begin{array}{l}0.07 \\
(0.77)\end{array}$ & $\begin{array}{l}0.07^{* *} \\
(2.78)\end{array}$ & $\begin{array}{c}0.09 \\
(1.07)\end{array}$ & $\begin{array}{l}0.03^{* *} \\
(3.73)\end{array}$ & $\begin{array}{l}0.10^{* *} \\
(3.58)\end{array}$ & $\begin{array}{l}0.046^{* *} \\
(4.70)\end{array}$ & $\begin{array}{l}0.11^{* *} \\
(3.73)\end{array}$ \\
\hline \%1985-90 For. Immigrants & $\begin{array}{c}0.10 \\
(1.21)\end{array}$ & $\begin{array}{r}0.68^{*} \\
(2.36)\end{array}$ & $\begin{array}{c}0.08 \\
(0.99)\end{array}$ & $\begin{array}{c}0.55 \\
(1.95)\end{array}$ & $\begin{array}{l}-0.06 \\
(0.69)\end{array}$ & $\begin{array}{l}-0.85^{* *} \\
(3.22)\end{array}$ & $\begin{array}{r}0.20^{*} \\
(2.14)\end{array}$ & $\begin{array}{l}-0.35 \\
(1.26)\end{array}$ \\
\hline $\begin{array}{l}\text { State Fixed Effects } \\
\mathrm{R}^{2}\end{array}$ & $\begin{array}{l}\mathrm{Y} \\
0.885\end{array}$ & $\begin{array}{l}Y \\
0.902\end{array}$ & $\begin{array}{l}Y \\
0.873\end{array}$ & $\begin{array}{l}\mathrm{Y} \\
0.895\end{array}$ & $\begin{array}{l}Y \\
0.749\end{array}$ & $\begin{array}{l}\text { Y } \\
0.795\end{array}$ & $\begin{array}{l}Y \\
0.691\end{array}$ & $\begin{array}{l}\mathrm{Y} \\
0.769\end{array}$ \\
\hline $\mathrm{N}$ & 735 & 735 & 735 & 735 & 2,288 & 2,288 & 2,288 & 2,288 \\
\hline
\end{tabular}

*significant at the $5 \%$ level, two tail test, ** significant at the $1 \%$ level, two tail test

From column (1), we see that lower MSA county income inequality is associated with suburban status relative to central city/single-county status, increased MSA population, higher labor force participation rates, greater percentage of the population 65 and over and greater average number of children in the family. Conversely, higher income inequality is associated with greater standard deviation in education; greater college attainment among the adult population; higher numbers of families headed by females; greater employment shares in personal services, agriculture, forestry, and fisheries services, and trade (where the average coefficient across all industries is 0.06 ); greater percentage of income from selfemployment; and log of family income. Greater recent structural change (19881990 ISC) was nearly significant, while neither employment growth variable approached statistical significance. ${ }^{18}$

${ }^{16}$ There is no reason to suspect that there was anything systematic about these 86 counties. The descriptive statistics were virtually the same in the entire sample of 3,109 counties as in the subsample of 3,023 counties.

${ }^{17} \mathrm{We}$ also estimated White-heteroscedasticity corrected t-statistics, but they were essentially the same as the reported OLS estimates. Note that in the following discussion we assume a normal distribution for the regression coefficients. As shown in Greene (1997, pp. 276-277), this is always true asymptotically regardless of whether the dependent variable or the residual is distributed normally. Thus, with the large sample sizes in our regressions, our hypothesis tests should be reasonably accurate.

${ }^{18}$ Dropping labor force participation rates, average income, and industry shares from the specification does not change the employment growth results. 
Several combinations of the 1980-90, 1985-90, and 1988-90 ISC variables were tried. The 1988-90 ISC variable typically yielded the best results, suggesting that family income inequality is positively related to industrial structural change in the short run (less than five years). ${ }^{19}$ The insignificance of the 1980-1990 ISC variable suggests that structural change does not have long-run effects on income inequality, likely as a result of adjustments such as reemployment in the county at comparable wage rates and out-migration. Since industry composition is already accounted for, structural change has independent effects beyond just different industry mixes. That is, income inequality is not just influenced by having, for example, a smaller manufacturing sector and a larger service sector, but by the actual process of workers moving from one sector to another.

One possible concern with the ISC results, though, is that county differences in restructuring may be related to industry composition. For example, counties with more manufacturing may have experienced greater sectoral reallocation in the previous decade. To examine this, we omit the industry composition variables from the model and report the results in columns (3) and (4). As expected, the ISC coefficient increases in magnitude and statistical significance, while the other results are almost identical. This indicates that the ISC results in columns (1) and (2) are not an artifact of severe multicollinearity. ${ }^{20}$

There were a few modest differences between the results based on the Gini coefficient and those based on the variance of the log of income. From column (2), we see that MSA population and the college graduate population share lose significance, but barely. Male labor force participation becomes insignificant, while recent immigration and the 18- to 24-year-old population share become significant.

The results in columns (5)-(8) suggest some differences for nonmetro counties. We test whether the coefficient differences between the MSA and nonmetro regressions are statistically significant using the Chow test, with the results shown in Table 4. For the independent variables as a whole, the null hypothesis that the corresponding metro and nonmetro coefficients are equal can be easily rejected at the $5 \%$ level for both the Gini and variance models. Moreover, when considering the individual variable groups shown in Table 3 one at a time, the null hypothesis

\footnotetext{
${ }^{19}$ In selecting the ISC variables, the variables were entered into the regression individually and two at a time. When entered two at a time, the ISC variables were insignificant. When entered individually, the 1980-90 ISC coefficient was never close to statistical significance. The 1988-90 ISC coefficient was largest, and significant in both cases when entered individually for metro counties. By comparison, when the 1985-90 ISC was used in place of the 1988-90 ISC variable, the resulting coefficient equaled $0.26(t=.09)$ in the Gini model and $21.52(t=2.11)$ in the variance model. As described in the Data Appendix, experiments were done by omitting counties where less than 95 percent and 99 percent, respectively, of the county's employment was disclosed at the industry level (in constructing the ISC variables). Here, the magnitude of the ISC coefficients and their t-statistics were larger, while the other results were essentially unchanged. This suggests that the influence of the ISC variables may be slightly understated by our using the 90 percent disclosure criterion.

${ }^{20}$ Further sensitivity analysis (not shown) was conducted to examine possible nonlinear effects for some variables. First, the square of the log of average family income was added to the base Gini model in column (1) (similar results followed for the variance model). In this case, the income squared coefficient was not statistically significant $(t=1.43)$. Second, we added squares of the African-American population share and the non-AfricanAmerican minority population share to the Gini model. The quadratic African-American coefficient was negative and statistically significant, while the non-African-American square coefficient was insignificant. This result suggested that as the African-American share rises above 10.3 percent (which applies to about 237 MSA counties), a larger African-American share is consistent with less income inequality.
} 
that the corresponding metro and nonmetro coefficients are equal can again be rejected at the $5 \%$ percent level. That is, all of the main categories in Table 3 contribute to differences in the determinants of MSA and nonmetro income inequality.

\section{TABLE 4}

Chow Tests for Coefficient Differences Between the Metro and Nonmetro Specifications

\begin{tabular}{lcc}
\hline Variable Group & $\begin{array}{c}\text { Gini Models } \\
\text { column (1) vs. column (5) } \\
\text { F-statistic }\end{array}$ & $\begin{array}{c}\text { Variance of Log Income } \\
\text { column (2) vs. column (6) } \\
\text { F-statistic }\end{array}$ \\
\hline All Variables $^{\mathrm{a}}$ & 2.28 & 2.87 \\
& $(\mathrm{p}=.0001)$ & $(\mathrm{p}=.0001)$ \\
Metro/Nonmetro $^{\mathrm{b}}$ & 19.24 & 14.28 \\
Economic Development $^{\mathrm{b}}$ & $(\mathrm{p}=.0001)$ & $(\mathrm{p}=.0001)$ \\
Industry Composition $^{\mathrm{b}}$ & 7.21 & 8.06 \\
& $(\mathrm{p}=.0001)$ & $(\mathrm{p}=.0001)$ \\
Human K/Demographic & 2.54 & 1.98 \\
& $(\mathrm{p}=.0009)$ & $(\mathrm{p}=.0134)$ \\
& 2.06 & 5.89 \\
\hline
\end{tabular}

aThe Chow test for the joint null hypothesis that all of the variable coefficients in the MSA model equal the corresponding coefficients in the nonmetro specification.

${ }^{b}$ Chow test for the joint null hypothesis that the MSA coefficients in the variable group (from Table 3 ) equal the corresponding nonmetro variable coefficients. The test is conducted by interacting an MSA dummy with the variables in the variable group and including these variables in the pooled regression. The test statistic is the joint F-statistic regarding the statistical significance of the interaction variables. For more details, see Kmenta (1986, pp. 420-422).

As with the MSA results, there are few substantive differences between the nonmetro Gini and variance results, where again, for brevity, we will emphasize the Gini results. One pattern in the nonmetro results is that labor market factors appear to be more important in nonmetro counties. For example, structural change appears to be a relatively short-run phenomenon in MSAs. That is, the 1988-90 ISC variable is very close to being statistically significant for MSAs (at the $5 \%$ level) in both the Gini and variance specifications. However, the 1985-90 ISC variable (not shown) is only significant in the MSA variance specification $(t=2.11)$, being nowhere near significant for the MSA Gini specification $(t=0.09)$. By contrast, the 1985-90 ISC is the only significant ISC measure for nonmetro areas. ${ }^{21}$ Taken together, at least for the Gini results, these findings weakly suggest that industry reallocation has a less persistent effect in MSAs (i.e., two years versus five years). This may occur because metro counties have more variety than nonmetro counties with respect to employment opportunities, allowing MSA workers more quickly to obtain suitable employment matches with a level of earnings near pre-displacement levels. Nevertheless, the effect of industry restructuring (ISC coefficient) is larger in metro areas. Thus, it may be that the restructuring in metro areas may be more skill-biased than in nonmetro areas. ${ }^{22}$

\footnotetext{
${ }^{21}$ The analogous nonmetro 1988-90 ISC coefficients were $4.42(t=1.72)$ for the Gini model and $6.16(t=0.78)$ for the variance model.

${ }^{2}$ Several variables in the nonmetro Gini specification in column (5) were tested (not shown) for possible quadratic effects (similar findings followed for the variance model). First, the square of the log of average family income term was positive and statistically significant at the $5 \%$ level when added to the model, with a negative linear term. Yet, the marginal income effect on inequality was positive throughout the range of income in the sample (as was the case in column (5)), while the other results were unaffected. So, we did not explore this model further. We also added squares of the African-American population share and non-African-American population share to the model, but both were statistically insignificant.
} 
One striking pattern in both the MSA and nonmetro results is how much more important female labor force participation is in reducing income inequality than male participation. However, higher female labor force participation rates reduce income inequality more in MSA counties than in nonmetro counties, while male labor force participation reduced income inequality more in nonmetro counties than in metro counties. In fact, comparing the results in columns (1) and (5), the metro-nonmetro female and male labor force participation coefficients differ at the $5 \%$ level $(t=3.96, t=2.02)$. The greater effect of female labor force participation in metro areas may result from increased availability of child care, allowing females in metro areas to accept more full-time jobs and more responsibility on the job. The stronger income inequality-reducing effect for males in nonmetro areas may be because males who are induced into the nonmetro labor market are disproportionately from low-income families.

As indicated in Table 4, when taken as a group, the industry share coefficients differ between the MSA and nonmetro models. Yet, directly comparing the individual coefficients is complicated because they are interpreted as the effect of that industry relative to public administration (the omitted group), not relative to the average for all industries. Nonetheless, we can still obtain some insights into which industries contributed to the metro/nonmetro difference by noting that the average nonmetro industry share coefficient equaled 0.12 , versus 0.06 in the MSA results. Hence, the relatively lower nonmetro manufacturing share coefficients suggest that manufacturing has a more equalizing effect in nonmetro areas compared to the average nonmetro industry, perhaps because manufacturing is an especially important outlet for less-skilled nonmetro workers to obtain a "good" job. Certainly, the more equalizing effect for manufacturing has economic development implications in nonmetro areas. Greater employment shares in transportation, health services, personal services, business services, and education services lead to relatively lower family income inequality in MSA counties compared to nonmetro counties.

Income from self-employment is significantly less important in explaining nonmetro income inequality than MSA income inequality (in the Gini models, $t=9.40$ ). Nonmetro population verges on positive significance, contrasting with the negative effect for metro counties, although the difference between the metro and nonmetro Gini models is not quite statistically significant at the $5 \%$ level $(t=1.78)$. Recent employment growth (1988-1990), though insignificant, comes closer to being a factor in reducing income inequality for nonmetro areas.

Of particular importance, however, is that greater educational attainment reduces income inequality in nonmetro counties and increases income inequality in metro counties (though education standard deviation is insignificant in the nonmetro Gini regression). In fact, the difference between the MSA and nonmetro high school and college graduate coefficients is statistically significant (in the Gini models, $t=6.52$ and $t=20.85$, respectively). This suggests that lesser educated individuals have fewer opportunities to attain middle-class status in nonmetro areas 
than in metro areas. Also, there may be relatively greater demands for skill in metro areas, increasing the premium paid to education and skill, which widens the income distribution. In particular, the larger MSA college graduate coefficient is consistent with a greater skill-biased effect in MSAs.

The percent living in the same county in 1985 is insignificant in MSA counties, but positive and significant in nonmetro counties, although the difference between the two coefficients in the Gini models is not statistically significant $(t=0.60)$. Yet, at least for nonmetro counties, the negative and significant nonmetro original resident share suggests that greater residential mobility reduces income inequality. Thus, spatial mismatches caused by residential immobility should not be overlooked in nonmetro areas (though there could be other explanations associated with less gross in-migration). Particularly for the variance of the $\log$ of income model, the share of recent foreign immigrants is positively related to MSA family income inequality, but negative and significant for nonmetro counties. One possible explanation is that the attributes of MSA and nonmetro immigrants differ, although the difference between the metro and nonmetro foreign immigrant coefficient is only significant in the variance model (for the difference in the Gini models, $t=1.33$, in the variance models, $t=3.91$ ). Finally, the variation explained by the explanatory factors is higher for metro counties, suggesting additional unobserved factors behind nonmetro income inequality.

\section{CONCLUSION}

This study examined the determinants of family income inequality using 1990 data for more than 3,000 U.S. metropolitan and nonmetropolitan counties. The use of county-level data allowed us to examine distinctions in the determinants of metro versus nonmetro county income inequality. The results revealed several differences between metro and nonmetro counties in the importance of various causes of income inequality.

In general, income inequality effects associated with labor market dynamics were more prominent in nonmetro areas. For example, the Gini results suggested that the effects of structural change appeared longer lasting in nonmetro areas, although the variance results were less clear. Correspondingly, recent employment growth verged on being significant in reducing income inequality in nonmetro areas, but not for metro areas. Variation in male labor force participation rates was more important for explaining nonmetro income inequality differences, while female labor force participation was more significant in explaining MSA income inequality differences. Increased employment shares in manufacturing reduced income inequality more in nonmetro areas. In addition, gross migration flows were significant in explaining nonmetro income inequality variation, but were not significant for explaining metro area differences. Educational attainment reduced income inequality in nonmetro areas, while increased college attainment increased income inequality in metro areas, possibly through greater relative demand for education and skill. 
Additional research into the link between local labor market dynamics and the well-being of nonmetro residents appears warranted. Nevertheless, our finding of stronger labor market effects on nonmetro income inequality suggests that increased emphasis be given to nonmetro areas in state and national economic development policies. State economic development policies that give the largest tax breaks for manufacturers locating in the poorer and most distressed nonmetropolitan areas appear warranted (e.g., the tiered tax credit system implemented in Georgia) (Governor's Development Council 1994). With less population mobility and accompanying longer-lasting effects of structural change, job retraining targeted to areas that have experienced restructuring also is suggested by the results. Correspondingly, more affordable, convenient child care in nonmetro areas may increase female labor force participation, and the benefits from fuller participation, and reduce nonmetro income inequality. Finally, the results suggest that it is particularly important for nonmetro areas to implement polices to increase the education attainment among its population, such as those aimed at reducing high school dropout rates.

\section{DATA APPENDIX}

The ISC is the sum of absolute changes in the share of industry employment between the initial period and the ending period divided by two. The industries are: farm; agriculture, forestry and fisheries services; mining; construction; manufacturing; transportation and public utilities; retail trade; wholesale trade; FIRE; services; and government. Almost one-third of counties had at least one industry whose employment value was not disclosed. We adjusted these counties in two ways. First, if the industry's employment was reported in either the previous year or the ensuing year, we substituted that value. Second, most of the nondisclosed employment values were for industries with very little employment, so we summed the county's industry shares that were disclosed. If the total disclosed employment share was greater than 90 percent of total employment, we assumed the amount of restructuring in the nondisclosed industries was equal to the restructuring in the disclosed industries. If the nondisclosed share was greater than 10 percent, these county observations were dropped.

The 90 percent disclosure threshold resulted in the omission of 86 counties ( 8 metro counties and 78 nonmetro counties), which accounted for about 0.6 percent of national employment. The largest omitted county had 68,000 employees. By contrast, studies based on County Business Patterns data only account for about 80 to 90 percent of total national employment due to incomplete industry coverage and similar nondisclosure problems. We also experimented with thresholds stricter than 90 percent (e.g., 95 and 99 percent), but our conclusions were generally unaffected by these changes. For example, a 95 percent disclosure criterion reduced the sample by 150 counties and a 99 percent disclosure criterion reduced the sample by 306 counties with, losses of 1 percent and 1.6 percent, respectively, of national employment. 


\section{REFERENCES}

Allen, Steven G., and Richard B. Freeman. "Quantitative Flexibility in the U.S. Labor Market." Unpublished, 1995. Mimeographed.

Bartik, Timothy J. "Who Benefits from Local Job Growth: Migrants or Original Residents." Regional Studies 27 (1993), 297-311.

. "The Effects of Metropolitan Job Growth on the Size Distribution of Family Income." Journal of Regional Science 34 (1994), 483-502.

. "The Distributional Effects of Local Labor Demand and Industrial Mix:

Estimates Using Individual Panel Data." Journal of Urban Economics 40 (1996), 150-178.

Blank, Rebecca M. "Disaggregating the Effect of the Business Cycle on the Distribution of Income." Economica 56 (1989), 141-163.

Blank, Rebecca M., and David Card. "Poverty, Income Distribution and Growth: Are They Still Correlated?" Brookings Papers on Economic Activity 2 (1993), 285-325.

Blau, Francine D., and Lawrence M. Kahn. "International Differences in Male Wage Inequality: Institutions versus Market Forces." Journal of Political Economy 104 (1996), 791-837.

Bluestone, Barry. "Comment." In Gary Burtless (ed.) Future of Lousy Jobs? Washington, D.C.: Brookings, 1990.

Borjas, George J., Richard Freeman, and Lawrence Katz. “On the Labor Market Effects of Immigration and Trade." In George J. Borjas (ed.) Immigration and the Work Force. Chicago: University of Chicago, 1992.

. "Searching for the Effect of Immigration on the Labor Market." American Economic Review 86 (1996), 246-251.

Borjas, George J., and Valerie A. Ramey. "Foreign Competition, Market Power, and Wage Inequality." Quarterly Journal of Economics 110 (1995), 1075-1110.

Bound, John, and George Johnson. "Changes in the Structure of Wages in the 1980s: An Evaluation of Alternative Explanations." American Economic Review 82 (1992), 371-392.

Bradbury, Katharine L. "The Changing Fortune of American Families in the 1980s." New England Economic Review (July/August 1990), 25-40.

Cancian, Maria, Sheldon Danziger, and Peter Gottschalk. "Working Wives and Family Income Inequality Among Married Couples." In Sheldon Danziger and Peter Gottschalk (eds.) Uneven Tides, Rising Inequality in America. New York: Russell Sage Foundation, 1993.

Carrington, William J., and Asad Zaman. "Interindustry Variation in the Costs of Job Displacement." Journal of Labor Economics 12 (1994), 243-275.

Cutler, David M., and Lawrence F. Katz. "Macroeconomic Performance and the Disadvantaged." Brookings Papers on Economic Activity 2 (1991), 1-74.

Davis, Steven J. "Cross Country Patterns of Change in Relative Wages." In O. Blanchard and S. Fisher (eds.) NBER Macroeconomic Annual 1992. Cambrídge, MA: MIT Press, 1992. 
Freeman, Richard, and Lawrence F. Katz. "Rising Inequality: The United States Vs. Other Advanced Countries." In R.B. Freeman (ed.) Working Under Different Rules. New York: Russell Sage Foundation, 1994.

Frey, William H. "Immigration and Internal Migration 'Flight' from US Metro Areas: Toward a New Demographic Balkanisation." Urban Studies 32 (1995), 733-757.

Garofalo, Gasper, and Michael S. Fogarty. "Urban Inequality and City Size: An Examination of Alternative Hypotheses for Large and Small Cities." Review of Economics and Statistics 61 (1979), 381-388.

Governor's Development Council. Building a New Economic Engine for the 21st Century: Strength From Diversity. Atlanta, GA, 1994.

Greene, William H. Econometric Analysis. Upper Saddle River, NJ: Prentice Hall, 1997.

Hirsch, Barry T. "Earnings Inequality Across Labor Markets: A Test of the Human Capital Model." Southern Economic Journal 45 (1978), 32-45.

Holzer, Harry. "The Spatial Mismatch Hypothesis: What has the Evidence Shown?" Urban Studies 28 (1991), 105-122.

Howland, Marie, and George E. Peterson. "Labor Market Conditions and the Reemployment of Displaced Workers." Industrial and Labor Relations Review 42 (1988), 109-122.

Ihlanfeldt, Keith R. "Information on the Spatial Distribution of Job Opportunities within Metropolitan Areas." Journal of Urban Economics 41 (1997), 218-242.

Jacobson, Louis S., Robert J. LaLonde, and Daniel G. Sullivan. "Earnings Losses and Displaced Workers." American Economic Review 83 (1993), 685-709.

Juhn, Chinhui, and Kevin M. Murphy. "Wage Inequality and Family Labor Supply." Journal of Labor Economics 15 (1997), 72-97.

Karoly, Lynn A. "The Trend in Inequality Among Families, Individuals, and Workers in the United States: A Twenty-Five Year Perspective." In Sheldon Danziger and Peter Gottschalk (eds.) Uneven Tides, Rising Inequality in America. New York: Russell Sage Foundation, 1993.

Karoly, Lynn A., and Gary Burtless. "Demographic Change, Rising Earnings Inequality, and the Distribution of Personal Well-Being, 1959-1989." Unpublished, 1995. Mimeographed.

Karoly, Lynn A., and Jacob A. Klerman. "Demographics, Sectoral Change, and Changing Relative Wages: A Regional Approach." Rand Research Working Paper 94-20, 1994.

Katz, Lawrence F., and Kevin M. Murphy. "Changes in Relative Wages, 1963-1987:

Supply and Demand Factors." Quarterly Journal of Economics 107 (1992), 35-78.

Katz, Lawrence F., and Lawrence H. Summers. "Industry Rents: Evidence and Implications." Brookings Papers on Economic Activity (Microeconomics), 1989. Kmenta, Jan. Elements of Econometrics. New York: Macmillan, 1986.

Kuznets, Simon. "Economic Growth and Income Inequality." American Economic Review 45 (1955), 1-28. 